\title{
Pengaruh Strategi Pemasaran Terhadap Keputusan Masyarakat Pembelian Produk Usaha Mikro Kecil Dan Menengah Di Kabupaten Tapanuli Selatan
}

\section{Mukti Simamora}

Program Studi Magister Manajemen, Universitas Muhammadiyah Sumatera Utara

Medan, Indonesia

\section{Hazmanan Khair}

Program Studi Magister Manajemen, Universitas Muhammadiyah Sumatera Utara Medan, Indonesia

Koresponden: hazmanankhair@umsu.ac.id

\begin{abstract}
The purpose of this study was to examine and analyze the effect of product, price, place, promotion on purchasing decisions in South Tapanuli Regency partially or simultaneously. The approach used in this study is a quantitative approach. The population in this study is all people who buy the product. The sample in this study used quota sampling totaling 100 people who bought MSME products. Data collection techniques in this study used documentation, observation, and questionnaire techniques. The data analysis technique in this study is the classical assumption test, multiple linear regression Hypothesis Testing and the coefficient of determination. Data processing in this study using the SPSS software program. The results of this study prove that partially and simultaneously product, price, place and promotion have a significant effect on purchasing decisions
\end{abstract}

keywords Product, Price, Place, Promotion, Purchase Decision

\section{PENDAHULUAN}

Masyarakat merupakan calon konsumen yang menjadi target ujung tombak perusahaan. Semua perusahaan berlomba-lomba atau bersaing jadi yang terdepan untuk memikat minat masyarakat untuk membali. Sebegitu pentingnya masyarakat bagi perusahaan sampai-sampai memerlukan strategi untuk mempengaruhi keputusan pembelian. Konsumen merupakan aset yang harus dibina, dijaga dan direbut hatinya untuk menjaga keberlangsungan perusahaan. Dalam keputusant masyarakat membeli harus menggunakan strategi pemasaran yang tepat. Pemasar dapat menggunakan strategi untuk mendukung keberlanjutan bisnis dalam kerbelangsungan hidup perusahaan (D’Souza et al, 2019). Selain itu Kualitas pelayanan yang baik akan berdampak pada niat pembelian konsumen (Hooper, Coughlan \& Mullen, 2013). Keputusan pembelian adalah semua perilaku sengaja dilandaskan pada keinginan yang dihasilkan ketika konsumen secara sadar memilih salah satu diantara tindakan alternatif yang ada. (Nitisusastro, 2012). Keputusan pembelian adalah suatu tindakan yang dilakukan konsumen untuk membeli produk. (Nel Arianty, 2016). Keputusan pembelian sangat penting untuk menentukan maju tidaknya suatu perusahaan dimasa yang akan datang. Keberhasilan perusahaan dalam mempengaruhi konsumen dalam keputusan pembelian sangat di dukung melalui upaya membangun komunikasi dengan memenuhi kebutuhan yang 
konsumen inginkan, menciptakan berbagai produk yang bervariatif serta berbagai pilihan produk itu sendiri, dan menciptakan produk yang sebelumnya belum pernah dibutuhkan oleh konsumen (Asututi \& Abdullah, 2018).

Keputusan pembelian seseorang dapat dikatakan sesuatu yang unik, karena preferensi dan sikap terhadap obyek setiap orang berbeda. Selain itu konsumen berasal dari beberapa segmen, sehingga apa yang diinginkan dan dibutuhkan juga berbeda. Masih terdapat banyak faktor yang berpengaruh terhadap keputusan pembelian. Produsen perlu memahami perilaku konsumen terhadap produk atau merek yang ada di pasar, selanjutnya perlu dilakukan berbagai cara untuk membuat konsumen tertarik terhadap produk yang dihasilkan (Yurita et al., 2017) Pengambilan keputusan adalah proses pengenalan masalah (problem recognition), pencarin informasi, evaluasi (penilaian) dan seleksi dan alternatif produk, seleksi saluran distribusi dan pelaksanaan keputusan terhadap produk yang akan digunakan atau dibeli oleh konsumen (Munandar, 2001).

Strategi pemasaran merupakan pernyataan (baik secara implisit maupun eksplisit) mengenai bagaimana suatu merek atau lini produk mencapai tujuannya. Strategi pemasaran sebagai alat fundamental yang direncanakan untuk mencapai tujuan perusahaan dengan mengembangkan keunggulan bersaing yang berkesinambungan melalui pasar yang dimasuki dan program pemasaran yang digunakan untuk melayani pasar sasaran tersebut (Tjiptono, 2008). Strategi pemasaran mutlak dilakukan, agar perusahaan tetap bertahan dan makin maju dan berkembang. Strategi pemasaran adalah logika pemasaran di mana unit bisnis berharap untuk mencapai tujuan pemasarannya. Kekalahan dalam persaingan, kurang memperhatikan lingkungan pemasaran, perkembangan budaya masyarakat, teknologi, kualitas produk, promosi, pelayanan, distribusi pelatihan, politik dan lain sebagainya (Kotler \& Keller, 2009).

Strategi pemasaran pada dasarnya adalah rencana yang menyeluruh, terpadu dan menyatu dibidang pemasaran, yang memberikan panduan tentang kegiatan yang akan dijalankan untuk dapat tercapainya tujuan pemasaran suatu perusahaan. Bauran pemasaran (marketing mix) merupakan kombinasi dari empat variabel yang dapat menunjang kegiatan pemasaran perusahaan, yaitu: produk, harga, tempat dan promosi (Ross et al., 2009). Produk Merupakan keseluruhan konsep objek atau proses yang memberikan nilai manfaat kepada konsumen. Yang perlu diperhatikan dalam produk adalah konsumen tidak membeli fisik dari produk itu saja, tetapi membeli benefit dan value dari produk tersebut. Setiap perusahaan hendaknya dapat memilih secara tepat jelas barang (Firaus, 2017). Harga merupakan salah satu variabel pemasaran yang sangat penting dalam memberikan penilaian terhadap produk yang akan dilaksanakan. Harga adalah jumlah uang yang dibutuhkan untuk memperoleh berbagai kombinasi sebuah produk yang menyertainya (Firaus, 2017). Pada kehidupan sehari-hari dapat dirasakan bahwa suatu produk yang dihasilkan dengan kualitas yang baik, yang pantas dan produknya bermanfaat bagi masyarakat. Jika perusahaan tidak memperkenalkannya kepasar keadaan ini maka salah satu caranya yang efektif dengan mengadakan promosi. Promosi merupakan komunikasi yang persuasive, mengajak mendesak, membujuk, menyakinkan. Ciri-ciri dari komunikasi yang persuasive membujuk adalah ada komunikator yang secara terencana mengatur berita atau informasi dan cara penyampaiannya untuk mendapatkan akibat tertentu dalam sikap dan tingkah laku si penerima. Keuntungan bagi produsen ialah promosi membeli barang karena tertarik akan mereknya. Promosi menimbulkan keuntungan terhadap merek (Firaus, 2017).

Pada era perekonomian modern, produsen tidak hanya langsung menjual produknnya kepada konsumen akhir, tetapi juga sudah menggunakan jasa dari berbagai 
pihak seperti: perantara agen, distributor dan sebagainya. Tempat menunjukkan berbagai kegiatan yang dilakukan oleh produsen untuk mendistribusikan suatu produk yang dihasilkan dapat diperoleh dan tersedia bagi konsumen pada waktu dan tempat yang tepat dimana konsumenpun berada. Produsen hendaknya memperhatikan unsur-unsur yang terkait dalam bauran distribusi terdiri dari sistem saluran, daya jangkau, lokasi, persedian, dan transportasi (Firaus, 2017). Usaha, Mikro, Kecil dan Menengah yang disingkat dengan UMKM salah satu usaha yang menopang perekonomian. Kabupaten Tapanuli Selatan merupakan sebuah kabupaten di Sumatera Utara yang beribukotakan Siporok. Berdasarkan observasi peneliti terhadap UMKM yang terdapat di kabupaten Tapanuli Selatan dimana produk-produk UMKM sangat beragam. ada UMKM yang bergerak dibidang kuliner (dodol, kerupuk sambal, ikan saleh, rumah makanan, roti, gorengan dan lain-lain), pandai besi, buah-buahan (salak dan kopi), sayur-sayuran, gula aren, konveksi (batik Tapsel, ulos, bulang, tepak siri dan laian-lain). Karena begitu beragamnya bidang UMKM tersebut, maka peneliti memfokuskan pada produk kuliner UMKM di Kabupaten Tapanuli Selatan. Adapun produk yang ditawarkan kurang diminati oleh masyarakat, karena produk yang ditawarkan kurang bervariasi (bentuknya, pembungkusnya, warnanya dan rasanya dan lain-lain). Dimana produk olahan cenderung menoton hanya terfokus pada satu jenis produk saja. Produknya tidak ada tanda masa ekspayetnya, kadang dijumpai ada yang masuk angin dan kemasannya tidak menarik. Selanjutnya pada harga dimana harga yang ditawarkan cenderung lebih tinggi dibanding dengan harga di tempat lainnya. Harga tidak sesuai dengan manfaat yang diharapkan karena kualitas produknya tidak tahan lama dan masuk angin.

\section{LANDASAN TEORI}

\section{Keputusan Pembelian}

Keinginan membeli konsumen merupakan suatu hal yang tersembunyi dalam hati konsumen yang mana tak ada seorang pun yang bisa tau apa yang diinginkan dan yang diharapkan oleh konsumen. Niat membeli terlihat dari perilaku konsumen dan sikap terhadap suatu produk dan keyakinan tersebut juga akan menyebabkan naik turunnya minat beli konsumen. Menurut (Sangadji \& Sopia, 2013) mendefinisikan "keputusan sebagai pemilihan suatu tindakan dari dua pilihan alternatif atau lebih seorang konsumen yang hendak memilih harus memiliki pilihan alternatif". Suatu keputusan tanpa pilihan disebut "pilihan hobson".

Menurut (Setiadi, 2013) mendefinisikan bahwa suatu keputusan (decision) melibatkan pilihan di antara dua atu lebih alternatif tindakan (atau perilaku). Keputusan selalu mensyaratkan pilihan di antara beberapa perilaku yang berbeda. Selanjutnya menurut (N Arianty, 2016) "keputusan pembelian adalah tahap dalam proses pengambilan keputusan pembeli dimana konsumen benar-benar membeli". Pengambilan keputusan merupakan suatu kegiatan individu yang secara langsung terlibat dalam mendapatkan, mempergunakan dan mengatur pembeli produk maupun jasa.

\section{Indikator Keputusan Pembelian}

Indikator keputusan pembelian merupakan tindakan yang dilakukan oleh konsumen dalam upaya memecahkan masalah dalam upaya pemenuhan kebutuhan. Sebelum memutuskan untuk melakukan pembelian konsumen sering kali di hadapkan pada alternatif yang beragam. Menurut (Rahmadika \& Kristaningsih, 2018) adalah sebagai berikut: 
1. Prioritas pembelian, dimana seseorang memprioritaskan yang menjadi kebutuhan dari dirinya sendiri.

2. Kemudahan mendapat/memperoleh, dimana konsumen mendapatkan informasi yang detail untuk memperoleh produk yang di inginkan.

3. Pertimbangkan manfaat, konsumen lebih mengutamakan kualitas dari produk yang ingin dibeli.

4. Keyakinan dalam membeli, timbul keyakinan pada diri individu terhadap produk tersebut sehingga menimbulkan keputusan (proses akhir) untuk memperolehnya dengan tindakan yang di sebut membeli.

Proses pembelian berlangsung jauh sebelum pembelian aktual dan berlanjut jauh sesudahnya. Untuk itu pemasar perlu berfokus pada seluruh proses pengambilan keputusan bukan hanya pada proses pembeliannya saja.

\section{Produk}

Produk merupakan titik pusat dari kegiatan pemasaran karena produk merupakan hasil dari suatu perusahaan yang dapat ditawarkan ke pasar untuk di konsumsi dan merupakan alat dari suatu perusahaan untuk mencapai tujuan dari perusahaannya. Suatu produk harus memiliki keunggulan dari produk-produk yang lain baik dari segi kualitas, desain, bentuk, ukuran, kemasan, pelayanan, garansi, dan rasa agar dapat menarik minat konsumen untuk mencoba dan membeli produk tersebut. Pengertian produk (product) menurut (Kotler \& Keller, 2012) adalah segala sesuatu yang dapat ditawarkan ke pasar untuk mendapatkan perhatian, dibeli, digunakan, atau dikonsumsi yang dapat memuaskan keinginan atau kebutuhan. Secara konseptual produk adalah pemahaman subyektif dari produsen atas sesuatu yang bisa ditawarkan sebagai usaha untuk mencapai tujuan organisasi melalui pemenuhan kebutuhan dan kegiatan konsumen, sesuai dengan kompetensi dan kapasitas organisasi serta daya beli pasar. Selain itu produk dapat pula didefinisikan sebagai persepsi konsumen yang dijabarkan oleh produsen melalui hasil produksinya. Produk dipandang penting oleh konsumen dan dijadikan dasar pengambilan keputusan pembelian.

\section{Indikator Produk}

Kualitas produk adalah kemampuan suatu produk untuk melaksanakan fungsinya meliputi, daya tahan keandalan, ketepatan kemudahan operasi dan perbaikan, serta atribut bernilai lainnya

Dimensi kualitas produk menurut (Tjiptono, 2008) mengenukakan, bahwa kualitas produk memiliki beberapa dimensi antara lain :

1. Kinerja (Performance) merupakan karakteristik operasi dan produk inti (core product) yang dibeli.

2. Ciri-ciri atau keistimewaan tambahan (Features) yaitu karakteristik sekunder atau pelengkap.

3. Kesesuaian dengan spesifikasi (Conformance to Spesification) yaitu sejauh mana karakteristik desain dan operasi memenuhi standar yang telah ditetapkan sebelumnya.

4. Keandalan (Reliability) yaitu kemungkinan kecil akan mengalami kerusakan atau gagal pakai.

5. Daya tahan (Durability) berkaitan dengan berapa lama produk tersebut dapat terus digunakan. Dimensi ini mencakup umur teknis maupun umur ekonomis. 


\section{Harga}

Agar dapat sukses dalam memasarkan suatu barang atau jasa, setiap perusahaan harus menetapkan harganya secara tepat. Harga merupakan satu-satunya unsur bauran pemasaran yang memberikan pemasukan atau pendapatan bagi perusahaan. Menurut (Peter \& Oloson, 2012) Harga adalah suatu nilai tukar yang biasa disamakan dengan uang atau barang lain untuk manfaat yang diperoleh dari suatu barang atau jasa bagi seseorang atau kelompok pada waktu dan tempat tertentu.

Selanjutnya menurut (Kotler \& Amstrong, 2012) "harga adalah sejumlah uang yangditagih atas suatu produk atau jasa, atau jumlah semua nilai yang diberikan olehpelanggan untuk mendapatkan keuntungan dari memiliki atau menggunakan suatuproduk atau jasa". Sedangkan menurut (Assauri, 2012) "harga merupakan beban atau nilai bagikonsumen, yang didapatkan dengan memperoleh dan menggunakan suatu produk, Termasuk biaya keuangan dari konsumsi, di samping biaya sosial yang bukankeuangan, seperti dalam bentuk waktu, upaya, psikis, risiko dan prestise atau gengsisosial".

\section{Indikator Harga}

Menurut (Kotler \& Amstrong, 2012) menjelaskan ada empat yang menjadi indikator harga, yaitu:

1. Kesesuaian harga dengan kualitas produk

Harga sering dijadikan sebagai indikator kualitas bagi konsumen orang sering memilih harga yang lebih tinggi diantara dua barang karena mereka melihat adanya perbedaan kualitas. Apabila harga lebih tinggi orang cenderung beranggapan bahwa kualitasnya juga lebih baik

\section{Daya saing harga}

Konsumen sering membandingkan harga suatu produk dengan produk lainnya. Dalam hal ini mahal murahnya harga suatu produk sangat dipertimbangkan oleh konsumen pada saat akan membeli produk tersebut.

3. Kesesuaian harga dengan manfaat produksi

Konsumen memutuskan membeli suatu produk jika manfaat yang dirasakan lebih besar atau sama dengan yang telah dikeluarkan untuk mendapatkannya. Jika konsumen merasakan manfaat produk lebih kecil dari uang yang dikeluarkan maka konsumen akan beranggapan bahwa produk tersebut mahal dan konsumen akan berpikir dua kali untuk melakukan pembelian ulang.

4. Harga mempengaruhi daya beli konsumen

Konsumen sering membandingkan harga suatu produk dengan produk lainnya. Dalam hal ini mahal murahnya harga suatu produk sangat dipertimbangkan oleh konsumen pada saat akan membeli produk tersebut.

\section{Tempat}

Lokasi adalah suatu keputusan perusahaan untuk menentukan tempat usaha, menjalankan kegiatan usaha atau kegiatan operasional, dan mendistribusikan barang atau jasa yang menjadi kegiatan bisnisnya kepada konsumen. Pentingnya lokasi bagi perusahaan atau pengusaha sangat mempengaruhi keputusan sasaran pasar dalam menentukan keputusan pembeliannya. Menurut (Kasmir, 2016) tempat dapat diartikan sebagai tempat untuk memajangkan barang-barang dagangannya. Lokasi merupakan aspek penting dalam saluran distribusi, lokasi yang baik dapat menjamin tersedianya akses yang cepat, yang dapat menarik sebagian besar konsumen. Place (Tempat) berarti 
kemana tempat/lokasi yang dituju, bagaimana saluran distribusinya, berapa banyak saluran, dan kondisi para penyalur yang diperlukan.

Lokasi menurut (Tjiptono, 2008) lokasi mengacu pada berbagai aktivitas pemasaran yang berusaha memperlancar dan mempermudah penyampaian atau penyaluran barang dan jasa dari produsen kepada konsumen. Sedangkan menurut (Kotler \& Amstrong, 2012) "place include company activities that make the product available to target consumers". Kemudian menurut (Lupiyoadi \& Hamdani, 2011) "lokasi adalah keputusan yang dibuat perusahaan atau instansi pendidikan berkaitan dengan di mana operasi dan stafnya akan ditempatkan".

\section{Indikator Tempat}

Indikator Tempat (Place) Menurut (Tjiptono, 2008) variable lokasi lebih memakai indikator berikut :

1.Keterjangkauan lokasi

Jarak yang mampu di capai agar mempermudah didalam pembelian suatu produki

2.Kelancaran akses menuju lokasi

Mudahnya dijangkau konsumen untuk menuju lokasi

3.Kedekatan lokasi

Kedekatan lokasi dengan target pasar

\section{Promosi}

Setelah perusahaan menentukan produk yang bermutu, menetapkan harga yang sesuai dengan nilai produk, dan menetapkan produk pada tempatnya yang mudah dijangkau oleh konsumen, aktivitas selanjutnya yang harus diperhatikan oleh perusahaan adalah melakukan promosi.Promosi merupakan salah satu faktor penentu keberhasilan suatu program pemasaran. Menurut (Alma, 2018) promosi itu adalah sejenis komunikasi yang memberi penjelasan yang meyakinkan calon konsumen tentang barang dan jasa. Sedangkan menurut (Lamb et al., 2001) promosi adalah komunikasi dari para pemasar yang menginformasikan, membujuk, dan mengingatkan para calon pembeli suatu produk dalam rangka mempengaruhi pendapat mereka atau memperoleh suatu respons. Selanjutnya menurut (Cannon \& McCharthy, 2008) promosi adalah mengomunikasikan informasi antara penjual dan pembeli potensional atau orang lain dalam saluran untuk memengaruhi sikap dan perilaku.

\section{Indikator promosi}

Selain memperhatikan alat-alat promosi penjualan perusahaan harus bisa memilih indikator-indikator promosi penjualan yang tepat dalam mempromosikan produk.

Menurut (Kotler \& Amstrong, 2012) indikator promosi antara lain:

1. Frekuensi promosi

Jumlah promosi yang dilakukan dalam waktu melalui media promosi.

2. Kualitas promosi

Tolak ukur seberapa baik promosi dilakukan.

3. Kuantitas promosi

Nilai atau jumlah yang diberikan konsumen terhadap promosi.

4. Waktu promosi

Seberapa lama jangka waktu promosi dilaksanakan atau dilakukan oleh perusahaan.

5. Ketepatan atau kesesuaian promosi

Faktor yang dilakukan untuk mencapai target promosi. 


\section{METODOLOGI PENELITIAN}

Penelitian dilaksanakan mulai bulan Februari 2021 sampai dengan Agustus 2021, penelitian ini penulis ini menggunakan pendekatan penelitian kuantitatif dan asosiatif. Populasi dalam penelitian ini adalah masyarakat yang membeli produk UMKM di Kabupaten Tapanuli Selatan. berdasarkan dari seluruh populasi maka penulis menetapkan sampel sebanyak 100 orang masyarakat yang malakukan pembelian di UMKM Tapanuli Selatan penulis akan mengumpulkan 10 sampel per harinya. pengambilan sampel dengan cara teknik accidental sampling yaitu siapa saja yang secara kebetulan bertemu dengan penulis yang bisa dijadikan sebagai pengambilan data. Sampel penelitian ini dibatasi hanya pada masyarakat yang malakukan pembelian di UMKM di Kabupaten Tapanuli Selatan. Teknik analisis data dalam penelitian ini uji asumsi klasik, regresi linier berganda Uji Hipotesis dan koefesien determinasi. Pengolahan data dalam penelitian ini menggunakan program software SPSS .

\section{HASIL PENELITIAN DAN PEMBAHASAN}

Sebelum melakukan analisis regresi berganda terlebih dahulu dilakukan uji lolos kendala liner atau uji asumsi klasik. Tujuan dilakukannya uji asumsi klasik adalah untuk mengetahui Apakah suatu variabel bormal atau tidak. Normal disini dalam arti mempunyai distribusi data yang normal. Normal atau tidaknya data berdasarkan patokan distribusi normal data dengan mean dan standar deviasi yang sama. Jadi asumsi klasik pada dasarnya memiliki kriteria-kriteria sebagai berikut:

Uji normalitas dilakukan untuk mengetahui Apakah variabel dalam sebuah model regresi, yaitu variabel terikat dan variabel bebas berdistribusi secara normal atau tidak.

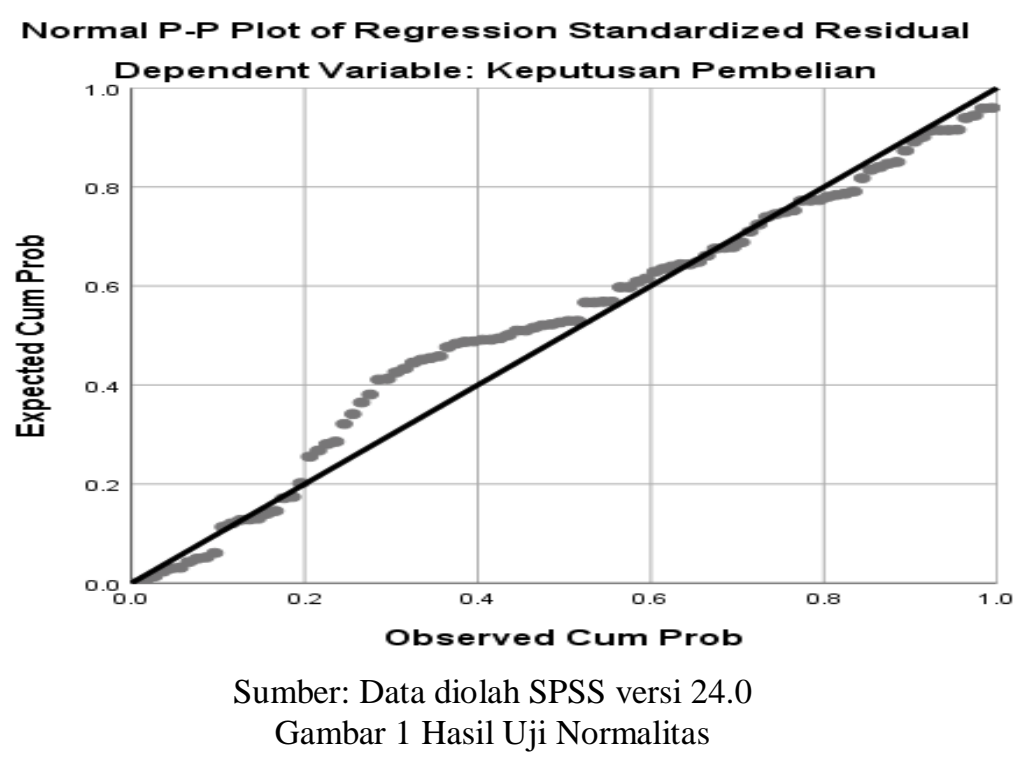

Pada grafik normal p-plot terlihat pada gambar diatas bahwa pola grafik normal terlihat dari tititk-titik yang menyebar disekitar garis diagonal dan penyebarannya mengikuti arah garis diagonal, maka dapat disimpulkan bahwa model regresi telah memenuhi asumsi normalitas. 


\section{Tabel 1 Hasil Uji Multikolonieritas}

\begin{tabular}{|c|c|c|c|c|c|c|c|c|}
\hline \multicolumn{9}{|c|}{ Coefficients $^{a}$} \\
\hline \multirow{2}{*}{\multicolumn{2}{|c|}{ Model }} & \multicolumn{2}{|c|}{$\begin{array}{l}\text { Unstandardized } \\
\text { Coefficients }\end{array}$} & \multirow{2}{*}{$\begin{array}{c}\begin{array}{c}\text { Standardize } \\
\text { d }\end{array} \\
\text { Coefficients } \\
\text { Beta }\end{array}$} & \multirow[b]{2}{*}{$t$} & \multirow[b]{2}{*}{ Sig. } & \multicolumn{2}{|c|}{ Collinearity Statistics } \\
\hline & & B & Std. Error & & & & $\begin{array}{c}\text { Toleranc } \\
\mathrm{e}\end{array}$ & VIF \\
\hline \multirow[t]{5}{*}{1} & (Constant) & -.185 & 1.038 & & -.178 & .859 & & \\
\hline & $\begin{array}{l}\text { Strategi } \\
\text { Produk }\end{array}$ & .290 & .048 & .331 & 6.099 & .000 & .257 & 3.886 \\
\hline & Harga & -.200 & .061 & -.199 & -3.249 & .002 & .201 & 4.977 \\
\hline & Tempat & .320 & .091 & .232 & 3.503 & .001 & .172 & 5.819 \\
\hline & Promosi & .598 & .079 & .627 & 7.565 & .000 & .110 & 9.087 \\
\hline
\end{tabular}

a. Dependent Variable: Keputusan Pembelian

Sumber: Data diolah SPSS versi 24.00

Dari tabel 1 dapat dilihat bahwa variabel strategi produk memiliki nilai tolerance sebesar $0.257>0.10$ dan nilai VIF sebesar $3.886<10$. Variabel harga nilai tolerance sebesar $0.201>0.10$ dan nilai VIF sebesar $4.977<10$. Variabel tempat memiliki nilai tolerance sebesar $0.172>0.10$ dan nilai VIF sebesar $5.819<10$. Variabel promosi nilai tolerance sebesar $0.110>0.10$ dan nilai VIF sebesar $9.087<10$. Dari masing-masing variabel memiliki nilai tolerance $>0.10$ dan nilai $\mathrm{VIF}<10$, dengan demikian dapat disimpulkan bahwa tidak terjadi gejala multikolinearitas dalam penelitian ini.

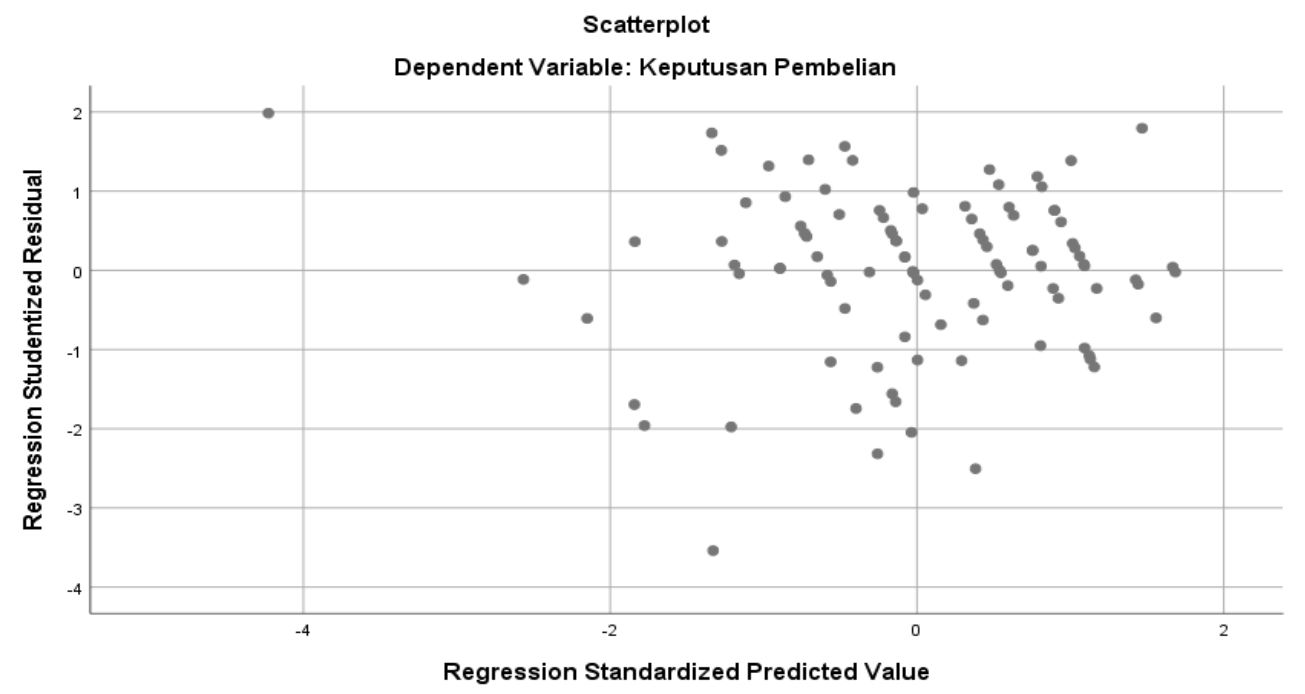

Sumber: Data diolah SPSS versi 24.00

\section{Gambar 2 Hasil Uji Heteroskedastisitas}

Berdasarkan gambar 2 diatas, dapat diketahui bahwa data (titik-titik) menyebar secara merata diatas dan dibawah garis nol, tidak berkumpul di satu tempat, serta tidak membentuk satu pola tertentu sehingga dapat disimpulkan bahwa pada uji regresi ini tidak terjadi heterokedastisitas.

Tabel 2 Hasil Regresi Linier Berganda

\begin{tabular}{|l|c|c|c|c|c|}
\hline \multicolumn{7}{|c|}{ Coefficients $^{\mathbf{a}}$} & \\
\hline \multirow{3}{*}{ Model } & \multicolumn{3}{|c|}{$\begin{array}{c}\text { Standardized } \\
\text { Coefficients }\end{array}$} & & \multirow{2}{*}{ Sig. } \\
\cline { 2 - 4 } & Unstandardized Coefficients & B & Std. Error & Beta & S \\
\cline { 2 - 6 } & & &
\end{tabular}




\begin{tabular}{|l|l|r|r|r|r|r|}
\hline 1 & (Constant) & -.185 & 1.038 & & -.178 & .859 \\
\cline { 2 - 7 } & Strategi Produk & .290 & .048 & .331 & 6.099 & .000 \\
\cline { 2 - 7 } & Harga & -.200 & .061 & -.199 & -3.249 & .002 \\
\cline { 2 - 7 } & Tempat & .320 & .091 & .232 & 3.503 & .001 \\
\cline { 2 - 7 } & Promosi & .598 & .079 & .627 & 7.565 & .000 \\
\hline \multicolumn{2}{|l}{ a. Dependent Variable: Keputusan Pembelian } \\
\hline
\end{tabular}

Sumber: Data diolah SPSS versi 24.00

Dari tabel 4.9 diatas diketahui nilai-nilai sebagai berikut :

$\begin{array}{lll}\text { 1. } & \text { Konstanta } & =-0.185 \\ \text { 2. } & \text { Strategi Produk } & =0,290 \\ \text { 3. } & \text { Harga } & =-0.200 \\ \text { 4. } & \text { Tempat } & =0,320 \\ \text { 5. } & \text { Promosi } & =0.598\end{array}$

Hasil tersebut dimasukkan kedalam persamaan regresi linier berganda sehingga diketahui persamaan berikut :

$$
Y=-0.185+0,290 X_{1}-0,200 X_{2}+0,320 X_{3}+0,598 X_{4}
$$

Jadi persamaan diatas bermakna jika :

1. Konstanta sebesar -0.185 menunjukkan bahwa apabila semua variabel independen strategi produk, strategi harga, strategi tempat dan strategi promosi diasumsikan bernilai nol, maka nilai dari keputusan pembelian adalah sebesar -0.185

2. Nilai koefisien regresi strategi produk sebesar 0,290 menunjukkan bahwa apabila nilai variabel strategi produk miningkat sebesar satu satuan, maka keputusan pembelian meningkat sebesar 0,290 satuan dengan asumsi variabel independen lainnya bernilai nol

3. Nilai koefisien regresi harga sebesar $-0,200$ menunjukkan bahwa apabila nilai variabel harga miningkat sebesar satu satuan, maka kpeutusan pembelian meningkat sebesar -0.200 satuan dengan asumsi variabel independen lainnya bernilai nol.

4. Nilai koefisien regresi tempat sebesar 0,320 menunjukkan bahwa apabila nilai variabel tempat miningkat sebesar satu satuan, maka keputusan pembelian meningkat sebesar 0,320 satuan dengan asumsi variabel independen lainnya bernilai nol.

5. Nilai koefisien regresi promosi sebesar 0,598 menunjukkan bahwa apabila nilai variabel promosi miningkat sebesar satu satuan, maka keputusan pembelian meningkat sebesar 0,598 satuan dengan asumsi variabel independen lainnya bernilai nol.

\section{Pengujian Hipotesis}

\section{Tabel 3 Hasil Uji t}

\begin{tabular}{|c|c|c|c|c|c|c|}
\hline \multicolumn{7}{|c|}{ Coefficients $^{a}$} \\
\hline \multirow{2}{*}{\multicolumn{2}{|c|}{ Model }} & \multicolumn{2}{|c|}{ Unstandardized Coefficients } & \multirow{2}{*}{$\begin{array}{c}\begin{array}{c}\text { Standardized } \\
\text { Coefficients }\end{array} \\
\text { Beta }\end{array}$} & \multirow[b]{2}{*}{$t$} & \multirow[b]{2}{*}{ Sig. } \\
\hline & & B & Std. Error & & & \\
\hline \multirow[t]{5}{*}{1} & (Constant) & -.185 & 1.038 & & -.178 & .859 \\
\hline & Strategi Produk & .290 & .048 & .331 & 6.099 & .000 \\
\hline & Harga & -.200 & .061 & -.199 & -3.249 & .002 \\
\hline & Tempat & .320 & .091 & .232 & 3.503 & .001 \\
\hline & Promosi & .598 & .079 & .627 & 7.565 & .000 \\
\hline
\end{tabular}

a. Dependent Variable: Keputusan Pembelian

\section{Sumber : SPSS 24.00}

Hasil pengujian statistik pada tabel diatas dapat dijelaskan sebagai berikut:

1. Pengaruh Strategi Produk Terhadap Keputusan Pembelian 
Nilai $t_{\text {hitung }}$ untuk variabel strategi produk adalah 6.099 dan $t_{\text {tabel }}$ dengan $\alpha=5 \%$ diketahui sebesar 1,985 dengan demikian $t_{\text {hitung }}$ lebih besar dari $t_{\text {tabel }}$ dan nilai signifikan strategi promosi sebesar $0.000<0.05$ artinya dari hasil tersebut didapat kesimpulan bahwa $\mathrm{H}^{0}$ ditolak ( $\mathrm{H}^{\mathrm{a}}$ diterima) menunjukkan bahwa strategi promosi berpengaruh signifikan terhadap keputusan pembelian produk kuliner UMKM di Kabupaten Tapanuli Selatan.

\section{Pengaruh Strategi Harga Tehadap Keputusan Pembelian}

Nilai $t_{\text {hitung }}$ untuk variabel strategi harga adalah -3.249 dan $t_{\text {tabel }}$ dengan $\alpha=5 \%$ diketahui sebesar 1,985 dengan demikian $t_{\text {hitung }}$ lebih besar dari $t_{\text {tabel }}$ dan nilai signifikan harga sebesar $0.002<0.05$ artinya dari hasil tersebut didapat kesimpulan bahwa $\mathrm{HO}$ ditolak (Ha diterima) menunjukkan bahwa strategi harga berpengaruh negatif signifikan terhadap keputusan pembelian produk kuliner UMKM di Kabupaten Tapanuli Selatan.

\section{Pengaruh Strategi Tempat Terhadap Keputusan Pembelian}

Nilai $t_{\text {hitung }}$ untuk variabel strategi tempat adalah 3.503 dan $t_{\text {tabel }}$ dengan $\alpha=5 \%$ diketahui sebesar 1,985 dengan demikian $t_{\text {hitung }}$ lebih besar dari $t_{\text {tabel }}$ dan nilai signifikan strategi tempat sebesar $0.001<0.05$ artinya dari hasil tersebut didapat kesimpulan bahwa $\mathrm{H}^{0}$ ditolak ( $\mathrm{H}^{\mathrm{a}}$ diterima) menunjukkan bahwa strategi tempat berpengaruh signifikan terhadap keputusan pembelian produk kulioner UMKM di Kabupaten Tapanuli Selatan.

\section{Pengaruh Strategi Promosi Terhadap Keputusan Pembelian}

Nilai $t_{\text {hitung }}$ untuk variabel strategi promosi adalah 7.565 dan $t_{\text {tabel }}$ dengan $\alpha=$ $5 \%$ diketahui sebesar 1,985 dengan demikian $t_{\text {hitung }}$ lebih besar dari $t_{\text {tabel }}$ dan nilai signifikan strategi promosi sebesar $0.000<0.05$ artinya dari hasil tersebut didapat kesimpulan bahwa $\mathrm{H}^{0}$ ditolak ( $\mathrm{H}^{\mathrm{a}}$ diterima) menunjukkan bahwa strategi promosi berpengaruh signifikan terhadap keputusan pembelian pada produk kuliner UMKM di Kabupaten Tapanuli Selatan.

Tabel 3 Hasil Uji F

\begin{tabular}{|l|l|r|r|r|r|r|}
\hline \multicolumn{7}{|c|}{ ANOVA $^{\mathrm{a}}$} \\
\hline Model & Sum of Squares & Df & Mean Square & F & Sig. \\
\hline 1 & Regression & 1219.391 & 4 & 304.848 & 306.789 & $.000^{\mathrm{b}}$ \\
\cline { 2 - 7 } & Residual & 94.399 & 95 & .994 & & \\
\cline { 2 - 7 } & Total & 1313.790 & 99 & & & \\
\hline a. Dependent Variable: Keputusan Pembelian \\
\hline
\end{tabular}

Sumber : SPSS versi 24.00

Dari hasil diatas dapat dilihat bahwa nilai $\mathrm{F}_{\text {hitung }}$ sebesar 306.789 dengan tingkat signifikan sebesar 0.000. Sedangkan nilai $F_{\text {tabel }}$ diketahui sebesar 3.09. berdasarkan hasil tersebut dapat diketahui bahwa $\mathrm{f}_{\text {hitung }}>\mathrm{f}_{\text {tabel }}(306.789>3.09)$ artinya $\mathrm{H}_{0}$ ditolak. Jadi dapat disimpulkan bahwa strategi produk, strategi harga, strategi tempat, strategi promosi secara bersama-sama berpengaruh signifikan terhadap keputusan pembelian produk kuliner pada UMKM di Kabupaten Tapanuli Selatan. 
Tabel 4 Hasil Uji Koefisien Determinasi

\begin{tabular}{|c|c|c|c|c|}
\hline \multicolumn{5}{|c|}{ Model Summary ${ }^{b}$} \\
\hline Model & $\mathrm{R}$ & R Square & Adjusted R Square & Std. Error of the Estimate \\
\hline 1 & $.963^{a}$ & .928 & .925 & .99683 \\
\hline \multicolumn{5}{|c|}{ a. Predictors: (Constant), Promosi, Strategi Produk, Harga, Tempat } \\
\hline
\end{tabular}

Sumber: SPSS versi 24

Berdasarkan tabel diatas dapat dilihat bahwa nilai dari R square sebesar 0.928 yang berarti 92,8 dan hal ini menyatakan bahwa variabel strategi produk, strategi harga, strategi tempat, strategi promosi sebesar 92,8\% untuk mempengaruhi variabel keputusan pembelian. Selanjutnya selisih $100 \%-92,8 \%=7,2 \%$. Hal ini menujukkan $7,2 \%$ tersebut adalah variabel lain yang tidak berkontribusi terhadap penelitian keputusan pembelian.

\section{PEMBAHASAN}

\section{Pengaruh Strategi Produk Terhadap Keputusan Pembelian}

Berdasarkan penelitian yang diperoleh mengenai pengaruh strategi produk terhadap keputusan pembelian UMKM di kabupaten Tapanuli Selatan hasil uji hipotesis menunjukkan bahwa nilai $t_{\text {hitung }}$ untuk variabel strategi produk adalah 6.099 dan $t_{\text {tabel }}$ dengan $\alpha=5 \%$ diketahui sebesar 1,985 dengan demikian $t_{\text {hitung }}$ lebih besar dari $t_{\text {tabel }}$ dan nilai signifikan strategi produk sebesar $0.000<0.05$ artinya dari hasil tersebut didapat kesimpulan bahwa H0 ditolak (Ha diterima) menunjukkan bahwa strategi produk berpengaruh signifikan terhadap keputusan pembelian pada UMKM di Kabupaten Tapanuli Selatan.

Dalam bisnis produk adalah barang atau jasa yang dapat diperjual belikan. Dalam marketing, produk adalah apapun yang bisa ditawarkan ke sebuah pasar dan bisa memuaskan sebuah keinginan atau kebutuhan. Dalam tingakat pengecer produk sering juga disebut sebagai merchandise. Semakin bagus kualitas produk yang diproduksi maka akan semakin memungkinkan untuk menarik sekelompok pembeli yang setia (Jonathan, 2017). Penelitian ini sejalan dengan penelitian terdahulu yang dilakukan oleh (Aditi \& Hermansyur, 2018); (Farisi, 2018), (Astuti \& Abdullah, 2017), (Lubis, 2015) dan (Fahmi, 2016) menyatakan bahwa secara parsial variabel produk berpengaruh positif terhadap kepetusan pembelian.

\section{Pengaruh Harga Terhadap Keputusan Pembelian}

Berdasarkan penelitian yang diperoleh mengenai pengaruh strategi harga terhadap keputusan pembelian UMKM di kabupaten Tapanuli Selatan hasil uji hipotesis menunjukkan bahwa Nilai $t_{\text {hitung }}$ untuk variabel strategi harga adalah 3.249 dan $t_{\text {tabel }}$ dengan $\alpha=5 \%$ diketahui sebesar 1,985 dengan demikian $t_{\text {hitung }}$ lebih besar dari $t_{\text {tabel }}$ dan nilai signifikan harga sebesar $0.002<0.05$ artinya dari hasil tersebut didapat kesimpulan bahwa $\mathrm{H} 0$ ditolak (Ha diterima) menunjukkan bahwa strategi harga berpengaruh negatif signifikan terhadap keputusan pembelian pada UMKM di Kabupaten Tapanuli Selatan. Dengan meningkatnya harga yang terjadi, diharapkan para UMKM yang ada agar dapat mencari bahan baku yang lebih murah, yang dapat meminimalisir biaya cost dengan menurunnya biaya cost para pegadang tidak perlu meningkat harga yang berdampak pada keputusan pembelian.

Harga bisa juga dikatakan dengan nilai tukar yang bisa disamakan dengan uang atau barang lain untuk manfaat yang diperoleh dari suatu barang atau jasa bagi seseorang atau kelompok pada waktu tertentu. Sikap dan tindakan konsumen terhadap suatu merk 
ditentukan oleh harga , maka harus bisa disesuaikan harga dengan manfaat suatu produk (Rizky \& Yasin, 2014). Penelitan ini sejalan dengan penelitian terdahulu yang dilakukan oleh (Akbar \& Haryoko, 2020) (Nahlia \& Hermani, 2019) menyimpulkan harga berpengaruh negatif terhadap keputusan pembelian. Sedangkan hasil penelitian terdahulu yang dilakukan oleh (Lubis, 2015), (A. E. Nasution \& Lesmana, 2018), (Lubis, 2015), (Fahmi, 2016), (Arif, 2016), (Dedek Kurniawan Gultom, 2017) dan (Wibisono \& Budiatmo, 2020) menunjukkan bahwa secara parsial ada pengaruh signifikan harga terhadap keputusan Pembelian.

\section{Pengaruh Strategi Tempat Terhadap Keputusan Pembelian}

Berdasarkan penelitian yang diperoleh mengenai pengaruh strategi tempat terhadap keputusan pembelian UMKM di kabupaten Tapanuli Selatan hasil uji hipotesis menunjukkan bahwa nilai $t_{\text {hitung }}$ untuk variabel strategi tempat adalah 3.503 dan $t_{\text {tabel }}$ dengan $\alpha=5 \%$ diketahui sebesar 1,985 dengan demikian $t_{\text {hitung }}$ lebih besar dari $t_{\text {tabel }}$ dan nilai signifikan strategi tempat sebesar $0.001<0.05$ artinya dari hasil tersebut didapat kesimpulan bahwa H0 ditolak (Ha diterima) menunjukkan bahwa strategi tempat berpengaruh signifikan terhadap keputusan pembelian pada UMKM di Kabupaten Tapanuli Selatan. Hal ini menunjukan bahwa semakin baik tempat penjual UMKM akan diikuti dengan kenaikan keputusan pembelian.

Penelitian ini sejalan dengan penelitian terdahulu yang dilakukan oleh (Munadi \& Ibrahim, 2017) menyimpulkan bahwa lokasi yang tepat akan sangat memungkinkan bahwa menambah atau menarik konsumen dalam membeli sebuah produk, dengan kata lain tempat atau lokasi sangat perpengaruh positif dan signifikan terhadap minat beli konsumen.

\section{Pengaruh Promosi Terhadap Keputusan Pembelian}

Berdasarkan penelitian yang diperoleh mengenai pengaruh strategi tempat terhadap keputusan pembelian UMKM di kabupaten Tapanuli Selatan hasil uji hipotesis menunjukkan bahwa nilai $t_{\text {hitung }}$ untuk variabel strategi promosi adalah 7.565 dan $t_{\text {tabel }}$ dengan $\alpha=5 \%$ diketahui sebesar 1,985 dengan demikian $t_{\text {hitung }}$ lebih besar dari $t_{\text {tabel }}$ dan nilai signifikan strategi promosi sebesar $0.000<0.05$ artinya dari hasil tersebut didapat kesimpulan bahwa $\mathrm{H} 0$ ditolak (Ha diterima) menunjukkan bahwa strategi promosi berpengaruh signifikan terhadap keputusan pembelian pada UMKM di Kabupaten Tapanuli Selatan. Hal ini menunjukan semain baik promosi yang dilakukan akan meningkatkan keputusan pembelian karena promosi yang dilakukan akan mengenalkan produk-produk yang dipasarkan kepada konsumen sehingga menarik minat untuk melakukan pembeli.

Dalam hal ini hubungan promosi penjualan terhadap keputusan pembelian sangatlah erat. Ini dikarenakan promosi penjualan menjadi program yang menentukan dalam pembelian konsumen terhadap produk. Semakin bagus promosi yang dilakukan perusahaan akan memungkinkan akan menambah minat konsumen dalam membeli suatu produk (Yoebrilianti, 2018). Hasil penelitian yang dilakukan oleh (Sanjaya, 2015) dan (Aditi \& Hermansyur, 2018) menyatakan bahwa secara parsial variabel promosi berpengaruh positif terhadap kepetusan pembelian merek Honda di kota Medan.

\section{Pengaruh Produk, Harga, Tempat dan Promosi Secara Bersama Sama Terhadap Keputusan Pembelian}

Berdasarkan penelitian yang diperoleh mengenai pengaruh strategi produk, harga, tempat dan promosi secara bersama-sama terhadap keputusan pembelian UMKM di 
kabupaten Tapanuli Selatan. Hasil uji hipotesis menunjukkan bahwa nilai $\mathrm{F}_{\text {hitung }}$ sebesar 306.789 dengan tingkat signifikan sebesar 0.000. Sedangkan nilai $F_{\text {tabel }}$ diketahui sebesar 3.09. berdasarkan hasil tersebut dapat diketahui bahwa $\mathrm{f}_{\text {hitung }}>\mathrm{f}_{\text {tabel }}$ (306.789 > 3.09) artinya $\mathrm{H}_{0}$ ditolak. Jadi dapat disimpulkan bahwa strategi produk, strategi harga, strategi tempat, strategi promosi secara bersama-sama berpengaruh signifikan terhadap keputusan pembelian UMKM di Kabupaten Tapanuli Selatan. Hal ini menunjukan bahwa strategi pemasaran berpengaruh terhadap keputusan pembelian UMKM di Kabupten Tapanuli Selatan.

Strategi pemasaran merupakan pernyataan (baik secara implisit maupun eksplisit) mengenai bagaimana suatu merek atau lini produk mencapai tujuannya. Strategi pemasaran sebagai alat fundamental yang direncanakan untuk mencapai tujuan perusahaan dengan mengembangkan keunggulan bersaing yang berkesinambungan melalui pasar yang dimasuki dan program pemasaran yang digunakan untuk melayani pasar sasaran tersebut (Tjiptono, 2008). Strategi pemasaran mutlak dilakukan, agar perusahaan tetap bertahan dan makin maju dan berkembang. Strategi pemasaran adalah logika pemasaran di mana unit bisnis berharap untuk mencapai tujuan pemasarannya. Kekalahan dalam persaingan, kurang memperhatikan lingkungan pemasaran, perkembangan budaya masyarakat, teknologi, kualitas produk, promosi, pelayanan, distribusi pelatihan, politik dan lain sebagainya (Kotler \& Keller, 2009).

Strategi pemasaran pada dasarnya adalah rencana yang menyeluruh, terpadu dan menyatu dibidang pemasaran, yang memberikan panduan tentang kegiatan yang akan dijalankan untuk dapat tercapainya tujuan pemasaran suatu perusahaan. Bauran pemasaran (marketing mix) merupakan kombinasi dari empat variabel yang dapat menunjang kegiatan pemasaran perusahaan, yaitu: produk, harga, tempat dan promosi (Ross et al., 2009).

\section{KESIMPULAN}

Hasil penelitian dan pembahasan yang telah dikemukakan sebelumnya maka dapat diambil kesimpulan adalah sebagai berikut:

1. Strategi produk berpengaruh secara parsial terhadap keputusan pembelian pada produk kuliner UMKM di Kabupaten Tapanli Selatan

2. Strategi harga berpengaruh negatif secara parsial terhadap keputusan pembelian pada produk kuliner UMKM di Kabupaten Tapanli Selatan

3. Strategi tempat berpengaruh secara parsial terhadap keputusan pembelian pada produk kuliner UMKM di Kabupaten Tapanli Selatan

4. Strategi promosi berpengaruh secara parsial terhadap keputusan pembelian pada produk kuliner UMKM di Kabupaten Tapanli Selatan

5. Strategi produk, harga, tempat dan promosi berpengaruh secara simultan terhadap keputusan pembelian pada produk kuliner UMKM di Kabupaten Tapanli Selatan

\section{DAFTAR PUSTAKA}

Akbar, M. F., \& Haryoko, U. B. (2020). Pengaruh Promosi dan Harga Terhadap Keputusan Pembelian dan Dampaknya Terhadap Kepuasan Pelanggan Pada Alfamart Cabang Cikokol Tangerang. Jurnal Ekonomi Efektif, 2(2), 280-286.

Alma, B. (2018). Manajemen Pemasaran \& Pemasaran Jasa. Alfabeta.

Arianty, N. (2016). Manajemen Pemasaran. Perdana Publishing.

Arianty, Nel. (2016). Pengaruh Promosi dan Merek Terhadap Keputusan Pembelian.

Jurnal Prosiding Dies Natalies, 4(2), 76-87. 
Assauri, S. (2012). Manajemen Pemasaran. PT. Raja Grafindo Persada.

Asututi, R., \& Abdullah, I. (2018). Pengaruh Kualitas Produk dan Promosi Terhadap Keputusan Pembelian Pakaian Di Usaha Mikro Kecil Menengah. Kumpulan Penelitian Dan Pengabdian Dosen, 1(1), 1-10.

Cannon, P., \& McCharthy. (2008). Manajemen Pemasaran. Salemba Empat.

Kasmir. (2016). Manajemen Sumber Daya Manusia (Teori dan Praktik). PT. Raja Grafindo Persada.

Kotler, \& Keller. (2009). Manajemen Pemasaran. Erlangga.

Kotler, P., \& Amstrong. (2012). Marketing Management. Erlangga.

Kotler, P., \& Keller, K. L. (2012). Marketing Management. Pearson Education Inc.

Lamb, C. w, Hair, J. F., \& McDaniel, C. (2001). Pemasaran. Salemba Empat.

Lupiyoadi, R., \& Hamdani. (2011). Manajemen Pemasaran Jasa. Salemba Empat.

Nahlia, F., \& Hermani, A. (2019). Pengaruh Kualitas Produk, Harga dan Promosi Terhadap Keputusan Pembelian Kartu Prabayar XL. Diponegoro Journal of Management1, 20(2), 1-9.

Nitisusastro, M. (2012). Perilaku Konsumen dalam Perspektif Kewirausahaan. Alfabeta.

Peter, \& Oloson. (2012). Perilaku Konsumen dan Strategi Pemasaran. Erlangga.

Rahmadika, N. A., \& Kristaningsih, T. (2018). Pengaruh Brand Imange dan Gaya Hidup Terhadap Keputusan Pembelian Jeans Levi's (Studi Pada Masiswa Aktif DIV Manajemen Pemasaran Jurusan Administrasi Niaga Poleteknik Negeri Malang Tahun 2017/2018). Jurnal Aplikasi Bisnis, 4(2), 301-305.

Ross, S. A., Westerfield, R. W., \& Jordan, B. D. (2009). Manajemen Keuangan. Salemba Empat.

Sangadji, E. M., \& Sopia. (2013). Perilaku Konsumen Pendekatan Praktisi Disertai Himpunan Jurnal Penelitian. CV Andi Offset.

Setiadi, N. J. (2013). Perilaku Konsumen. Kencana Prenada Media Group.

Tjiptono. (2008). Strategi Pemasaran (Ketiga). Andi.

Yoebrilianti, A. (2018). Pengaruh Promosi Penjualan Terhadap Minat Beli Produk Fashion Dengan Gaya Hidup Sebagai Variabel Moderator. Jurnal Manajemen, $8(1), 20-41$.

Yurita, A., Makmur, \& Afrizal, A. (2017). Analisis Pengaruh Persepsi Konsumen Terhadap Keputusan Pembelian Sepeda Motor Honda Matic Di Dealer Prima Motor Pasri Pengarian. E-Jurnal Mahasiswa Prodi Manajemen, 4(1), 1-10. 